\title{
A (Rendörségi) Belügyi Szemlében közölt, az állambiztonság területével foglalkozó írások áttekintő elemzése az SzKP XXII. kongresszusát követö időszakban
}

\section{MEZEI József ${ }^{1}$}

\begin{abstract}
A hazai állambiztonsági szervezetek jelentős része 1953-tól a Belügyminisztérium keretében látta el feladatait. Ugyanezen év januárjában a Belügyminisztérium elindította a Rendőrségi Szemlét többek között azzal a céllal, hogy e tudományos folyóirat keretében helyet biztosítson a rendőrségi munka során összegyült tapasztalatok megosztásának, hogy irányt mutasson a rendőri állománynak, akik ezáltal hatékonyabban lesznek képesek az elméletet a gyakorlatban alkalmazni. Az 1963-tól Belügyi Szemleként kiadott folyóiratnak több olyan rovata is volt, amelyben az állambiztonság valamely szegmensét vizsgálták, mutatták be, de már az első évtől volt kifejezetten olyan rovata is, "A titkos háborúk történetéből" elnevezésü, amely teljes egészében azzal foglalkozott. A párt és az állambiztonsági szervek szoros kapcsolata okán figyelmet érdemel, hogy 1961 októberében került sor a Szovjetunió Kommunista Pártja XXII., míg 1962 novemberében a Magyar Szocialista Munkáspárt VIII. kongresszusára.

Jelen tanulmány célja annak áttekintése, hogy a kongresszusokat követő időszakban az ott elhangzottak hogyan jelentek meg a Rendőrségi (Belügyi) Szemlében az állambiztonság területével összefüggésben közzétett publikációkban.
\end{abstract}

Kulcsszavak: állambiztonság, Belügyi Szemle, elhárítás, titkos háború, párt

\section{Bevezetés}

Magyarországon 1950-től az államvédelmi feladatokat a katonai hírszerzés kivételével a Belügyminisztériumtól független Államvédelmi Hatóság (ÁVH) keretében látták el, amely a Minisztertanács alárendeltségében múködött, és az 1949. december

\footnotetext{
Mezei József egyetemi tanársegéd, Nemzeti Közszolgálati Egyetem; doktori hallgató, Nemzeti Közszolgálati Egyetem Rendészettudományi Doktori Iskola.

József Mezei Assistant Lecturer, University of Public Service; PhD student, University of Public Service Doctoral School of Police Sciences and Law Enforcement.

E-mail: mezei.jozsef@uni-nke.hu, ORCID: https://orcid.org/0000-0002-2625-6317
} 
28-án kiadott, 4353/1949. MT sz. rendelettel jött létre. Ez az állapot közel négy évig maradt fenn, amikor is a Minisztertanács 1953. július 17-i ülésén, az 500/6/1953. sz. határozattal az ÁVH-t összevonta a Belügyminisztériummal. Az 1956-os forradalom kitörésekor Nagy Imre, ${ }^{2}$ majd annak leverése után a Kádár-kormány ${ }^{3}$ is úgy foglalt állást, hogy az ÂVH szervezetét nem építik újjá. A forradalom leverését követő átszervezések eredményeként végül az államvédelmi feladatok végrehajtására a Belügyminisztérium II. (Politikai Nyomozó) Főosztályát hozták létre. ${ }^{4} \mathrm{Ez}$ az állapot egészen 1962-ig állt fenn, amikor is egy a Belügyminisztérium teljes szervezetét érintő, 1962. augusztus 15-vel hatályba lépő ismételt átszervezés részeként az állambiztonsági munkával foglalkozó szervezetek a Belügyminisztérium III. Főcsoportfőnöksége keretében folytatták tevékenységüket. Ez a rendszer kisebb változtatásokkal közel 30 évig működött.

A Belügyminisztérium 1953 januárjában elindította a Rendőrségi Szemle című folyóiratot, a rendőrség központi folyóirataként elsődlegesen azzal a céllal, hogy felületet biztosítsanak a rendőri munka során keletkezett tapasztalatok megosztásához. Elő kívánták segíteni ${ }^{5}$ a szocialista társadalomban szükséges rendőri munka módszereinek minél szélesebb körben való terjesztését, ezzel együtt a nyomokban még megtalálható kapitalista beidegződések felszámolását. Ezen túl az elmélet fontosságának hangsúlyozása, az előremutató gondolkodás, valamint a kommunista nevelés jelentek meg célként az elinduláskor. ${ }^{6}$ A Rendőrségi Szemle 1962. december 31-vel megszúnt, hogy átadja helyét ${ }^{7}$ az 1963 januárjától megjelenő Belügyi Szemlének, ${ }^{8}$ amely „szigorú pártfelügyelet, pártirányítás alatt állt". ${ }^{9}$

A Rendörségi Szemlében kevéssé, a Belügyi Szemlében viszont rendszeresen jelentek meg az állambiztonság területét érintő publicisztikák, sőt állambiztonsági témájú rovatok is indultak. Ilyenek voltak például az 1963 áprilisában útjára indított „A titkos háborúk történetéből” és az 1964 júliusában megjelenő „Állambiztonsági

2 Nagy Imre a Kossuth rádióban, 1956. október 28-án 17 óra 25-kor elhangzott beszédében kijelentette, hogy „a rend helyreállítása után egységes, új államrendőrséget szervezünk és az Államvédelmi Hatóságot megszüntetjük”.

3 A Kádár-kormány 1956. november 7-i első ülésén döntött arról, hogy az ÁVH-t nem szervezik újjá, a feladatok ellátása a rendőrségen belül egy osztály keretében fog megtörténni. A Magyar Forradalmi Munkás-Paraszt Kormány 5003/1956. (XI. 7.) BM sz. rendelete.

4 Az addig az Országos Rendőrfőkapitánysághoz tartozó Főosztályt 1957. május 6-án rendelték a belügyminiszter első helyettesének felügyelete alá.

5 Deák József: A Belügyi Szemle és jogelődei a mindenkori politika és a rendészettudomány szolgálatában (1918-1990). In Orbók Ákos (szerk.): A hadtudomány és a XXI. század. Budapest, Tanulmánykötet. Doktoranduszok Országos Szövetsége. 2016. 31-48.

6 Szerkesztőség: Előszó. Rendőrségi Szemle, 1. (1953), 1. 3-5.

A Rendörségi Szemle búcsúja. Rendôrségi Szemle, 10. (1962), 12. 1184.

8 A Belügyi Szemlét a Belügyminisztérium egységes szakfolyóirataként indították útjára. Létrehozásának oka, hogy a pártvezetés a belügyi munkatársaktól is „új munkastílust, magasabb színvonalú politikai és szakmai ismereteket követel. [...] a szocializmus ügyéhez való hűség és feltétlen odaadás első követelménye mellett növekvő erővel jelentkezik a másik, szintén elengedhetetlen követelmény: a hozzáértés, a szükséges ismeretek megkövetelése”. Kádár Jánosnak az MSZMP VIII. kongresszusán elhangzott beszámolójából. Belügyi Szemle, 1. (1963), 1. 129. Ezt az idézetet a Belügyi Szemle 1963-ban megjelent minden számának első oldalán közzétették.

9 Deák József: A Belügyi Szemle közpolitikai, rendészetelméleti és szerkezeti fejlődése a rendszerváltásig. Hadtudományi Szemle, 10. (2017), 2.345. 
cikkek" címet viselő rovatok. ${ }^{10}$ Ezen túlmenően számtalan esetben előfordult, hogy egyéb rovatokban közölt publikációk is érintették az állambiztonság területét. Ilyen volt például a „Politikai és egyéb szakelméleti cikkek” című rovat, amelyben az állambiztonsággal összefüggő jogszabályok bemutatása, magyarázata történt meg, vagy a „Lapszemle”, amelyben külföldi lapokból vettek át az állambiztonság területéhez kapcsolódó írásokat.

A szövetségesi rendszer jellegéből adódóan a Szovjet Kommunista Párt (SzKP) 1961. október 17. és 31. között megtartott XXII. kongresszusán történtek, illetve annak eredményei jelentős hatást gyakoroltak a többi szocialista ország működésére, terveire, fejlődési irányaira. A Magyar Szocialista Munkáspárt (MSzMP) Központi Bizottsága 1961. november 17-i határozata rögzítette, hogy „teljes mértékben egyetért” az SzKP által meghatározott irányvonallal. ${ }^{11} \mathrm{~A}$ magyar állampárt és a hazai államvédelmi szerv közötti szoros kapcsolat okán kiemelt jelentőségú volt az SzKP mellett az MSzMP 1962. november 20. és 24. között megtartott VIII. ${ }^{12}$ kongresszusa is.

Jelen tanulmány célja annak áttekintése, hogy a kongresszusokat követő időszakban a kongresszusokon elhangzott gondolatok közül melyek voltak azok, amelyek az állambiztonság témakörét érintették és megjelentek a Rendörségi (Belügyi) Szemle hasábjain.

\section{A kongresszusokon az állambiztonság kapcsán elhangzottak közvetlen megjelenése a publikációkban}

Az SzKP kongresszusán új pártprogramot fogadtak el, amely ismételten bírálta az imperialisták ${ }^{13}$ burzsoá és revizionista törekvéseit. ${ }^{14}$ „Az imperialisták nem akarnak belenyugodni vereségükbe, egy harmadik világháború előkészületein mesterkednek..." ${ }^{15}$ a nemzetközi kapcsolatokban erőpolitikát alkalmaznak. ${ }^{16}$ Ezen álláspontok egyértelműen fenntartották, sőt tovább erősítették a kommunista országok addigi ellenségképét. Nyikita Szergejevics Hruscsov, a párt első titkára beszédében részletesen foglalkozott a törvényesség kérdéskörével is. Ez a sztálini múlttól való elhatárolódást célozta, amely az állambiztonsági szerveknek is üzenetként szolgált, hiszen a törvénytelenségek egy jelentős része hozzájuk kötődött. A törvényesség kapcsán

10 Baranyó György (szerk.): A Belügyi Szemle (Rendôrségi Szemle) 1953-1977. évi cikkeinek összesített tartalommutatója. Budapest, BM Tanulmányi és Propaganda Csoportfőnökség, 1978. 5.

11 Csáki Ernő: A Szovjetunió Kommunista Pártja XXII. Kongresszusa után. Rendőrségi Szemle, 9. 12. (1961), 963.

12 A Magyar Szocialista Munkáspártot 1956. október 31-én alapították, de a kongresszusok számozásánál az elődpártok (Magyar Kommunista Párt, Magyar Dolgozók pártja) kongresszusainak számozását is figyelembe vették.

13 A dolgozatban az „imperialista” és vele összefüggésben az „imperializmus” szavakat a korabeli értelmezés alapján használom. Imperialista: „Az imperializmus alapján álló, annak politikáját folytató <személy, közösség>.”, míg az imperializmus: „Hódításra, gyarmatok szerzésére, népek elnyomására és világuralomra törekvő külpolitika.” - Bárczi Géza - Országh László: A magyar nyelv értelmező kéziszótára. Budapest, Akadémiai Kiadó, 1959.

14 Beér János: Proletárdiktatúra - össznépi állam. Rendôrségi Szemle, 10. (1962), 1. 4.

15 Gönczy György - Sepsei György: Az izgatásos bủncselekmények aktuális bűnüldözési problémái. Rendôrségi Szemle, 9. (1961), 12. 1006.

16 Csáki (1961) i. m. 969. 
az első titkár azt is megemlítette, hogy a bűnözők elleni fellépésben az állami szervek mellett meg fog növekedni a „dolgozók tömegszervezeteinek szerepe”, ami növelni fogja annak hatékonyságát. A pártprogramban rögzítették, hogy elsődlegesen a prevencióra kell törekedni a bűncselekmények kapcsán. ${ }^{17}$

A szovjet elképzelések szerint a különösen veszélyes büncselekmények esetén megoldás lehet például a sajtóban vagy a rádióban közzétett felhívás, vagy akár a releváns csoportok személyes tájékoztatása is. ${ }^{18}$

A Szovjetunióban fent megfogalmazott gondolatok az MSzMP Központi Bizottsága VIII. kongresszusán, ${ }^{19}$ illetve az azt megelőzően kiadott irányelvekben, ${ }^{20}$ illetve a kongresszust követően a szakmai gondolkodásban is tetten érhetők voltak.

„Az irányelvekben a következőket olvashatjuk: »A szocialista nemzeti egység politikai tartalma: harc a szocialista rendszer védelméért és fejlesztéséért, a szocializmus teljes győzelméért, a békéért, a nemzeti függetlenség védelméért, küzdelem a nemzetközi imperializmus, és a még, meglevő belső ellenséges erők és tendenciák ellen."21 Az irányelvekben foglaltak kapcsán kialakult politikai diskurzusban az imperialisták elleni küzdelemre vonatkozó felvetést tovább fejtve megjelent az a vélemény, hogy még mindig vannak olyanok a magyar társadalomban, akik nem fogadják el a politikai berendezkedést, befolyásolják őket a nyugati, tőkés világból érkező hatások, sőt egyesek tevékenyen is fellépnek a rendszer ellen. ${ }^{22}$

Ugyanez megjelent a kongresszuson is, ahol a résztvevők megerősítették a pártot abban, hogy jó úton halad. Az állambiztonság kapcsán pedig, hogy a fő feladat „minden rendszerellenes, reakciós politikai erővel szembeni fellépés, az aktív ellenséges elemek mind hatékonyabb elszigetelése, s ezzel párhuzamosan a még ingadozó, valamint megtévedt elemek megnyerésének elősegítése". ${ }^{23}$ A kongresszuson elhangzottak kapcsán pedig megjelent az a vélemény, miszerint a jövőben is fel kell lépni azon tevékenységek ellen, ami a pártot erről az útról letérítheti, továbbá harcolni kell „a liberalizmus, a revizionizmus” és „mindenféle káros maradvány és mindenféle bomlasztó" 24 törekvés ellen.

E gondolatokban több más mellett a nyugat által folytatott fellazítási ${ }^{25}$ politika húzódik meg, amely elleni fellépés markánsan tetten érhető volt az állambiztonsági

Csáki (1961) i. m. 973.

18 G. Kočarov: A társadalom bevonása a különösen veszélyes büncselekmények felderítésébe. Rendôrségi Szemle, 10. (1962), 9. 821.

19 1962. november 20-24. között ülésezett az MSzMP VIII. kongresszusa, amelyen 614 szavazati és 36 tanácskozási jogú küldött vett részt.

20 1962. augusztus 14-16.: a KB elfogadja a kongresszusi irányelveket.

${ }^{21}$ Csizmadia Ernő: A szocializmus teljes felépítésének útján. Rendőrségi Szemle, 10. (1962), 10. 906.

22 Csizmadia (1962) i. m. 906.

23 Bakóczi Antal: Az összeesküvés törvényi tényállási elemeiről. Belügyi Szemle, 1. (1963), 7. 23.

24 Balogh Sándor: A VIII. Kongresszus után. Rendörségi Szemle, 10. (1962), 12. 1092.

25 A szót a korabeli magyar belügyi értelmezés szerint használom. A célját tekintve a fellazítás: „A fellazítási taktika arra irányul, hogy a szocialista országokat elválassza egymástól, és a szocialista közösségtől, mindenekelőtt pedig a szocialista demokrácia fejlődését liberalizálássá változtassa, megvalósítsa a rendszer békés átalakulását, a tőke restaurálását.” - Bruzsa Gábor: A „fellazítási" taktika egyes megjelenési formái. Belügyi Szemle, 4. (1966), 1. 
szervek feladatkörében az 1960-as években. ${ }^{26}$ A II. világháborút követően a hidegháborús szembenállás felületeinek száma növekedett. A két nagyhatalom közötti közvetlen, nyílt fegyveres konfliktus lehetősége, ha nem is szűnt meg, de jelentősen csökkent. A kommunista blokk országaiban azonban azonosították az imperialisták egy másik eszközét, a fellazítási politikát, amely szintén a szocialista rendszerek megdöntését célozta például azzal, hogy az állampolgárokban bizalmatlanságot ébresztett, illetve elégedetlenséget szított az állampárt, és az általa fenntartott rendszer ellen. ${ }^{27}$

$\mathrm{Az}$ SzKP első titkárának a törvényesség fontosságára vonatkozó, fent idézett megállapítása visszaköszön Kádár János 1962-ben, egy csepeli gyűlésen elmondott beszédében: „[A] törvényesség a nép számára a legfontosabb dolgok egyike. Ezalatt persze nemcsak azt értjük, hogy senkit nem csuknak be olyasmiért, amit nem követett el, hanem azt is, hogy a kém csak reszkessen, s aki lopott, az féljen, mert az is hozzátartozik a szocialista törvényességhez, hogy a bűnös rettegjen a törvény erejétől." ${ }^{28}$ Kádár János ezen gondolatának első fele az SzKP első titkárjáéhoz hasonlóan a múlttól való elhatárolódást szolgálja. Annak tükrében viszont, hogy a fellazítási taktika mögött jellemzően az imperialista országok hírszerző szervei álltak, talán nem véletlen, hogy a pártvezető beszédében a bűncselekmények közül éppen a kémkedést nevesítette.

A Belügyi Szemle első számában az első publikáció Pap János Belügyminiszter tollából származott. A Belügyi szemle elé... című írásában szintén a két kongresszus gondolatai jelennek meg. Egyrészt a törvényesség hangsúlyozása és e téren a múlttal való szakítás. „Tanultunk a múlt hibáiból és ártatlanul senkit sem üldözünk.” Másrészt kicsit mélyebb szakmai értékelésben az imperialisták elleni küzdelem és annak társadalmi támogatottsága. Eszerint jóval kevesebb lett a rendszerellenes személyek száma, azonban sokszor ezen állampolgárok a törvénytelenségek elkövetésétől sem riadtak vissza. A társadalmi támogatottság, az állambiztonsági szervek munkájában is tetten érhető, ${ }^{29}$ amelynek eredményeként a Belügyminisztérium több kémet is leleplezett. ${ }^{30} \mathrm{~A}$ társadalom pozitívabb viszonyulása annak is köszönhető, hogy az állambiztonsági munkatársak többsége szerény, kulturált magatartású és cselekedeteiben megfontolt. ${ }^{31} \mathrm{Az}$ imperialisták fellazítási taktikáját, a hosszú távú bomlasztást az állampolgárok közül is támogatták néhányan, akik azonban jelentős csoportot nem alkottak. A kongresszus előtti években történt államellenes konspirált próbálkozások „nacionalista-soviniszta alapon álltak”, a legtöbb „»keresztényszocialista Magyarország< "megvalósításáról ábrándozott”. Ezen törekvések egyrészét a Nyugat támogatta, másik részében pedig a szervezkedők keresték a kapcsolatot a nyugati

\footnotetext{
26 A probléma megoldásának fontosságát mutatja, hogy a Belügyminisztérium külön utasítást adott ki a Fellazítás elleni fellépésre vonatkozóan. A Magyar Népköztársaság Belügyminiszterének 0024. számú parancsa - A Belügyminisztérium szerveinek az imperialisták fellazító politikája elleni harcáról és a további feladatairól. (Belügyminisztérium, 1966. június 3.).

27 Bedő János et alii: Az imperialisták fellazítási taktikája. Budapest, Kossuth, 1968. 6.

28 Timár István: A Magyar Népköztársaság Büntető Törvénykönyvéről. Rendôrségi Szemle, 10. 1. (1962), 12.

29 Köteles István: Az állambiztonsági munka alapja a szocialista törvényesség. Belügyi Szemle, 1. (1963), 6. 9.

30 Pap János: A „Belügyi Szemle” elé.... Belügyi Szemle, 1. (1963), 1. 9.

31 Köteles (1963) i. m. 9.
} 
szervezetekkel. A fasiszták és a szélsőséges nacionalisták a háború kirobbantásában látták a megoldást ebben az időben, amelynek megvalósításában a nyugatnémet revansista csoportosulásokban bíztak. ${ }^{32}$

\section{A törvényesség, a társadalmi kapcsolatok erösítése és az izgatás mint az állambiztonság egyik fö kihívása}

1961-ben új Büntető törvénykönyvet fogadtak el, ${ }^{33}$ amely a korábbiakhoz képest jelentősen eltért az államellenes bűncselekményekre vonatkozó szabályok tekintetében. Lényeges tartalmi változás volt, hogy az új látásmód szerint csak az a bủncselekmény számított állam elleninek, amely az állam mint jogi tárgy ellen irányult. Az állam elleni bűntett olyan cselekedet kellett legyen, amely az állam egészét, illetve az alkotmányban ${ }^{34}$ rögzített, a társadalom alappilléreként szereplő értékeket (a társadalom gazdasági rendje és politikai felépítménye) veszélyeztesse, mivel ezek a „népi demokratikus államrendszer megingatásának veszélyét” hordozták magukban. ${ }^{35}$ Az állam elleni bűntetteket a kódex IX. fejezete tartalmazta. A törvényi tényállások: az összeesküvés; lázadás; kártevés; rombolás; merénylet; izgatás; hazaárulás; ellenség támogatása; kémkedés és a feljelentési kötelezettség elmulasztása voltak. A cselekmények jobb differenciálhatósága érdekben újként jelent meg a törvényben a kártevés; a rombolás és a merénylet. ${ }^{36}$

A társadalom és az állambiztonsági szervek közötti együttmúködés szempontjából jelentôsége van a büntetőeljárásról szóló 1962. évi 8. sz. törvényerejű rendelet (Be.) hatálybalépésének. Az új Be. előtt az állambiztonság területén nem alkalmazták a szignalizációt, annak ellenére, hogy a szakmai és politikai álláspont alapján a búnözés megelőzése csak széles körű társadalmi támogatottság mellett lehetett eredményes. Ehhez viszont a társadalomnak rendelkeznie kell azokkal az ismeretekkel, információkkal, amelyek a kockázatokra, a megelőzéshez szükséges ismeretekre vonatkoznak, hiszen csak így tudják felismerni azt, ha az általuk tapasztaltakat jelezniük kell a hivatalos szerveknek. Ezek a tájékoztatások az ismeretek átadásán túl az éberséget is fokozták, felhívták a figyelmet arra, hogy az állambiztonsági kockázatok jelen vannak. A szignalizáció egy másik céljaként jelent meg, hogy a rendelkezésre álló információkat felhasználják „a társadalmi ráhatás, a dolgozó tömegek nevelése terén". A szignalizáció lehetett közvetlen, adott ügyet érintő és közvetett, amikor több bủncselekmény elemzése alapján általános következtetéseket, megállapításokat lehetett tenni a büncselekmények elkövetéseinek okaira, vagy az azt lehetővé tevő

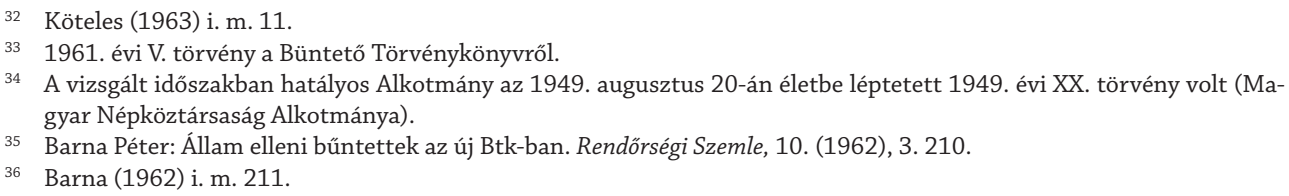


feltételekre. A szignalizáció célpontjai lehettek pártszervek, állami és társadalmi szervezetek. A szignalizációval kapcsolatban elvárásként jelent meg, hogy az legyen teljes és pontos. Tartalmaznia kellett a feltárt hiányosságokat, az azokból keletkező veszélyeket, valamint javaslatokat a hiányosságok megszüntetésére. Fontos volt viszszaigazolást kérni arról, hogy az intézkedéseket az érintett szervezetek megtették. A szignalizációt és a visszajelzéseket a belügyi szerveknek gyüjteni kellett, és félévente értékelni. A külső szignalizáció mellett a belügyi szervek felé küldött belső tájékoztatás is fontos volt, amely a belső hiányosságokra hívta fel a figyelmet. ${ }^{37}$

Az állambiztonsági szervek feladata az állam elleni büncselekmények megelőzése, felderítése, illetve az ezzel összefüggő nyomozati cselekmények lefolytatása volt, amelynek alapja a szocialista törvényesség. 1953 előtt, a Rákosi korszakban „az ellenséget elsősorban saját sorainkban kell keresni” és a „hibák mögött is az ellenség áll” volt a fő irányelv, amelynek eredményeként az ÁVH törvénytelenségekben volt érintett. A szakmai és pártértékelések szerint tehát az ellenforradalmat követően a törvényesség helyreállt, amellyel kapcsolatban lényegi elemek voltak a „bizonyítás” és a „terhelt jogainak biztosítása” ${ }^{38}$ terén bekövetkezett változások. Ezek hatására nőtt a társadalmi támogatottság, azonban „nem tűnt el teljesen és végleg a bizalmatlanság és a gyanakvás az állambiztonsági szervek munkájával szemben". ${ }^{39}$

A korabeli forrás szerint az 1960-as évek elején a politikai bűntettek száma csökkent, az „összeesküvés miatt elítéltek száma százalékban alig fejezhető ki és az államellenes bűncselekmények köre is jóformán csak az izgatásra szűkült" ${ }^{40}$ A sajtó részéről felmerült, hogy a sajtóban sem jelent meg közlemény ilyen jellegű cselekményekről, ami viszont biztosan nem azt jelentette, hogy nem történnek ilyen jellegü esetek. A sajtó képviselője szerint ez egyrészt csökkentette az éberséget, másrészt hamis szemléletmódot alakított ki az emberekben, harmadrészt a tájékozatlanság elidegeníti az állambiztonság munkatársait az emberektől. Annak, hogy az állambiztonsági szervek nem jelentetnek meg ilyen jellegű információkat a sajtóban az egyik oka, hogy nem alakított ki jó munkakapcsolatot a sajtó munkatársaival. ${ }^{41}$

\section{Az állambiztonsági szervek tevékenységét érintő egyéb témakörök}

A kongresszusokon elhangzott azon igény, hogy erősíteni kell a társadalommal való kapcsolatot, a magyar szakembereket is további gondolkodásra ösztönözte. Lehetséges megoldásként merült fel az, ha a belügyi vezetők közéleti tevékenységet folytatnak, és ennek során bővítik kapcsolatrendszerüket a politika, a kultúra és a gazdaság

\footnotetext{
37 Kása Tibor - Fenyvesi István: Szignalizáció az állam elleni bűnügyekben. Belügyi Szemle, 2. (1964), 7. 5-13.

38 Köteles (1963) i. m. 9.

39 Köteles (1963) i. m. 11.

40 Csendes Károly: Kormányhatározat a büntető-jogalkalmazásról. Belügyi Szemle, 1. (1963), 8. 6.

41 Szabó László: A rendőrség és a sajtó. Belügyi Szemle, 1. (1963), 9. 24.
} 
területén. Ezen kapcsolatrendszeren keresztül aztán ismereteket szerezhetnek a munkájuk ellátásához is. Értékelhetnek egy-egy témát, eseményt is a továbbiakban akár a szervezeten kívül is. Ez utóbbira volt már precedens, például a belügyi szerveknél kémelhárítás témakörében. Ezek során előfordult azonban, hogy a vezetők ezeknek az előadásoknak a megtartását a beosztottakra bízták, ami így gyakran nem megfelelő színvonalú volt, és sokszor a kitűzött célt sem érte el. Itt is felmerült az a megoldás, amit a szovjet oldalon a különösen veszélyes bűncselekmények kapcsán javasoltak, miszerint érdemes lehet a belügyi szervek munkájával kapcsolatos cikkek megjelenítése a sajtóban. ${ }^{42}$ A sajtó szerint a tájékoztatás mellett, illetve azzal párhuzamosan az írásoknak lehet oktató-nevelő funkciója, elősegítheti a prevenciót, csökkentheti a társadalomban a rendőrséggel szembeni idegenkedést, illetve a nyilvánosság bevonása hozzájárulhat egy adott ügy felderítéséhez is. ${ }^{43}$

Az imperialisták elleni küzdelem kapcsán, valamint az általuk folytatott fellazítás, az azzal szorosan összefüggő lélektani hadviselés, illetve annak a magyar jogban izgatásként történő lecsapódása arányaiban a legnagyobb mértékben volt jelen az átte-

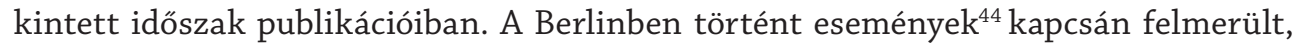
hogy az aktivizálhatja a hazai ellenséges elemeket, és habár az izgatás elleni fellépés elsődlegesen a politikai nyomozó szervek feladata volt, de emellett minden rendőri szerv kötelessége is. ${ }^{45} \mathrm{Az}$ izgatás több formában is megvalósult: szóban; falfestéssel; röplapozással. Ez utóbbi tevékenység általában szervezetszerű volt, és ezeknek az eseteknek „közvetlen vagy közvetett kapcsolata van egyes imperialista szervezetekkel”. ${ }^{4}$ $\mathrm{Az}$ izgatás ${ }^{47}$ mint állam elleni büncselekmény kapcsán egy aprólékosabb nyomozati munka igénye jelentkezett, amely már nemcsak a bűnös személyének megállapításához, az objektív ítélkezéshez szükséges ismereteket biztosította, hanem a nevelő jellegű tevékenységhez és a prevencióhoz is segítséget adott. ${ }^{48} \mathrm{E}$ büntettek eredményes nyomozásához a szakszerǔség és a legjobb tapasztalatok felhasználása mellett elengedhetetlen volt, hogy a rendőri szervek együttműködjenek, továbbá jelentős segítséget adhatott a feladatellátáshoz a „dolgozók legszélesebb rétegének támogatása”. 49 Az izgatásos ügyek kapcsán azonosított egyik információforrás a Szabad Európa rádió volt. ${ }^{50}$ A rádió hallgatásáról, illetve ellenséges propaganda folytatásáról a lakosságtól is

42 Vincze Béla: A parancsnokok közéleti tevékenységéről. Belügyi Szemle, 1. (1963), 1. 13-20.

43 Szabó (1963) i. m. 20.

44 1961. augusztus 13-án a Német Demokratikus Köztársaság egy szögesdrót kerítéssel elválasztotta Kelet- és Nyugat-Berlint egymástól. A szögesdrót helyén néhány nappal később elkezdték egy fal építését, ami, miután elkészült, közel 30 évre elválasztotta egymástól a város két felét.

45 Gönczy-Sepsei (1961) i. m. 1007.

46 Gönczy-Sepsei (1961) i. m. 1008.

47 A Belügyminisztérium III/III. Csoportfőnökség Ügyrendje. Belügyminisztérium, 1972.; Az izgatás elleni fellépés a BM III/III. Csoportfőnökség feladatkörébe tartozott.

48 Vágó Tibor: Az államrend elleni izgatás differenciálása és annak egyes kérdései a cselekmények felderítése és értékelése során. Belügyi Szemle, 1. (1963), 1. 21-28.

49 Kastyák János: Feliratos izgatás büntettének nyomozása a Helvéciai Állami Gazdaságban. Belügyi Szemle, 1. (1963), 1. 88 .

50 Kada Mihály - Hegedűs Kálmán: Névtelen fenyegető levelek és izgató röpcédulaterjesztők felderítése. Belügyi Szemle, 1. (1963), 4. 102. 
érkeztek bejelentések. Az izgatás felderítéséhez a konspirált figyelés, a levélküldemények ellenőrzése operatív eszközök használata, ${ }^{51}$ írás- ${ }^{52}$ és vegyiszakértő bevonása ${ }^{53}$ is elfogadott volt, ami jól mutatja, hogy az említett cselekmény elleni fellépés milyen fontos volt a hivatalos szervek, illetve az állampárt számára. Az elkövetők körében a hatóság szerint a maradiság és a konzervatív gondolkodás is tetten érhető volt. ${ }^{54}$

A szakmai álláspont szerint az izgatás mögött legnagyobb részt az Amerikai Egyesült Államok (United States of America - USA) által folytatott lélektani hadviselés húzódott meg, akik nyíltan vállalták, hogy céljaik eléréséhez igénybe vették a propaganda eszközét is. Szinte minden amerikai hírszerző szerv és az Észak-atlanti Szerződés Szervezete is rendelkezett lélektani hadviselést folytató központtal. Az USA által használt egyik - látszatra magánkézben lévő - lélektani hadviselő központ a fent már említett Szabad Európa Rádió volt. Ezen központok müködését a megcélzott országot jól ismerő szakértők segítették, akik a folyamatosan gyüitött információk feldolgozása által javaslatokat tudnak tenni a propaganda tartalmára, irányára. ${ }^{55}$

1963 áprilisában egy újabb rovattal bővült a Belügyi Szemle. „A titkos háborúk történetéből" címú rovat a történelem, leginkább a II. világháborúhoz köthető eseményein keresztül mutatta be a hírszerzők és a kémelhárítók feladatait és egymás elleni küzdelmét. Az érintett történetekben a vizsgált időszakban a volt náci Németország és az imperialista országok hírszerző szerveinek tevékenysége állt a középpontban.

A magyarországihoz hasonló problémákkal küzdött a vizsgált időszakban a Német Demokratikus Köztársaság (NDK) is az NDK belügyminisztere szerint. A nyugat-berlini, nyugat-németországi ügynökségek által folytatott kémkedés, izgatás, szabotázs számottevő anyagi és eszmei kárt okozott országuknak. A lefolytatott büntetőeljárásaik alátámasztották, hogy sok elkövetőt ideológiai ráhatással vettek rá bűncselekmények elkövetésére. Az NDK-ban is megjelent az SZKP XXII. kongresszusának azon gondolatmenete, miszerint elsődlegessé vált a törvényesség igénye. A nyomozások során az okok és feltételek mind teljesebb körü feltárása vált szükségessé, valamint a dolgozókkal való kapcsolat elmélyítése prevenciós céllal. Szintén fontos igényként jelent meg a bủnüldöző szervek munkatársai képzettségi szintjének emelése. ${ }^{56}$

\section{Befejezés}

$\mathrm{Az}$ áttekintett időszak alapján az SzKP XXII. kongresszusán meghatározott azon irányok, amelyek az állambiztonság kérdéskörét érintették rövid időn belül megjelentek a Belügyi Szemle oldalain. Azon témakörök, amelyek markánsan jelen voltak: a tör-

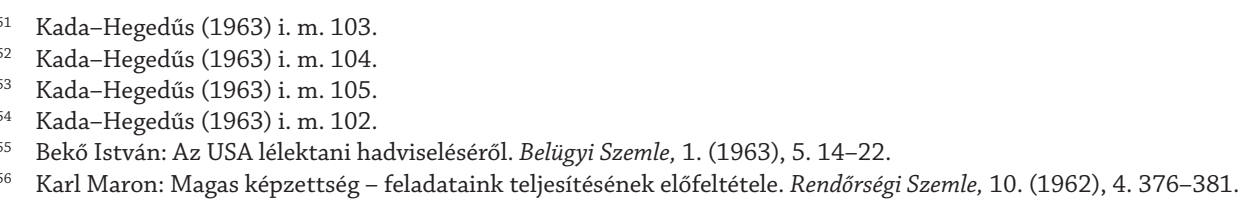


vényesség kérdésköre, amely elválaszthatatlanul összefonódott a múltól való teljes szakítással - amelyről persze tudjuk, hogy nem valósult meg, mert az ÁVH több munkatársa még később is jelen volt az állambiztonság szervezetében; a társadalommal való együttműködés szükségessége, ami szorosan összefügg az előző törekvéssel; valamint az imperialisták és a belső ellenséggel szembeni fellépés. A törvényesség kapcsán érdekes időbeli egybeesés a kongresszusok és az új Btk. és Be. bevezetése, ami az állambiztonság terén is változásokat hozott.

A kiemelt témakörök, így például a törvényességgel összefüggésben közölt publikációkban részletesen, a megértést segítő magyarázatokkal tárgyalták az állam elleni büncselekmények tényállásait. Egyes bemutatott esettanulmányok néha már túlzó egyszerúséggel mutattak rá a szakmaiság fontosságára, illetve a hibákkal való szembenézés „természetességére”. ${ }^{57}$ Azzal a szakmai felvetéssel azonban mindenképpen egyet kell most is érteni, hogy a társadalom bizalmának elnyeréséhez a munka során nem lehet nélkülözni a szakmaiságot és a törvényességet.

A hazai példák mellett, a nem vagyunk egyedül a problémáinkkal érzést is „becsempészte” a lapba a Belügyi Szemle szerkesztősége az NDK belügyminiszterének publikációján keresztül. Az írás - ami egy olyan jogi képzés megindítása kapcsán készült, ahova a rendészeti szervek munkatársai jelentkezhettek - minden olyan gondolatot megjelenített, amely az SzKP konferenciát követően a magyar állambiztonság szempontjából is releváns volt.

Az állambiztonsági munka jellege okán az információk védelme különösen fontos. A munkatársak szakmai képzésének/önképzésének egyik lehetséges megoldása viszont a szakmai folyóiratokban közölt hiteles, tudományos igényességű publikációk tanulmányozása. E kettő szempontot figyelembe véve kijelenthető, hogy egy minősített információk közlését is lehetővé tevő melléklete a Belügyi Szemlének megkönynyíthette volna a kitûzött célok elérését, amelynek igénye az évek során „időről időre felbukkan"-t. ${ }^{58}$

\section{IRODALOMJEGYZÉK}

A Belügyminisztérium III/III. Csoportfőnökség Ügyrendje. Belügyminisztérium, 1972. Online: www.abtl.hu/sites/default/files/forrasok/ugyrend_3.pdf

Bakóczi Antal: Az összeesküvés törvényi tényállási elemeiröl. Belügyi Szemle, 1. (1963), 7. 23-36.

Balogh Sándor: A VIII. Kongresszus után. Rendörségi Szemle, 10. (1962), 12. 1092-1097.

Baranyó György (szerk.): A Belügyi Szemle (Rendörségi Szemle) 1953-1977. évi cikkeinek összesített tartalommutatója. Budapest, BM Tanulmányi és Propaganda Csoportfőnökség, 1978.

Barna Péter: Állam elleni bűntettek az új Btk-ban. Rendőrségi Szemle, 10. (1962), 3. 210-223.

Beér János: Proletárdiktatúra - össznépi állam. Rendörségi Szemle, 10. (1962), 1. 3-11.

Bedő János - Hun Péter - Miklós Iván - Pálos Tamás - Tardos András: Az imperialisták fellazítási taktikája. Budapest, Kossuth, 1968.

\footnotetext{
7 Kiss József: Egy ellenforradalmi röpcédulaszórás nyomozásának tapasztalatai. Belügyi Szemle, 1. (1963), 8. $103-107$.

58 Deák József: A Belügyi Szemle a pártfórumok értékeléseiben (1973-1987). Belügyi Szemle - Ordinem Facere: A Belügyi Szemle folyóirat időszaki kiadványa, (2018), 1. 25.
} 
Bekő István: Az USA lélektani hadviseléséről. Belügyi Szemle, 1. (1963), 5. 14-22.

Bruzsa Gábor: A „fellazítási" taktika egyes megjelenési formái. Belügyi Szemle, 4. (1966), 1.

Csáki Ernő: A Szovjetunió Kommunista Pártja XXII. Kongresszusa után. Rendőrségi Szemle, 9. (1961), 12. 963-971.

Csizmadia Ernő: A szocializmus teljes felépítésének útján. Rendőrségi Szemle, 10. (1962), 10. 899907.

Csendes Károly: Kormányhatározat a büntető-jogalkalmazásról. Belügyi Szemle, 1. (1963), 8. 5-14.

Deák József: A Belügyi Szemle a pártfórumok értékeléseiben (1973-1987). Belügyi Szemle - Ordinem Facere: A Belügyi Szemle folyóirat idôszaki kiadványa, (2018), 1. 16-26.

Deák József: A Belügyi Szemle és jogelődei a mindenkori politika és a rendészettudomány szolgálatában (1918-1990). In Orbók Âkos (szerk.): A hadtudomány és a XXI. század. Tanulmánykötet. Budapest, Doktoranduszok Országos Szövetsége. 2016. 31-48.

Deák József: A Belügyi Szemle közpolitikai, rendészetelméleti és szerkezeti fejlődése a rendszerváltásig. Hadtudományi Szemle, 10. (2017), 2. 339-355.

Gönczy György - Sepsei György: Az izgatásos bűncselekmények aktuális bűnüldözési problémái. Rendörségi Szemle, 9. (1961), 12. 1006-1010.

Gy, T. A szicíliai partraszállás előkészítése. Belügyi Szemle, 1. (1963), 4. 87-94.

Kada Mihály - Hegedűs Kálmán: Névtelen fenyegető levelek és izgató röpcédulaterjesztők felderítése. Belügyi Szemle, 1. (1963), 4. 102-105.

Kastyák János: Feliratos izgatás bűntettének nyomozása a Helvéciai Állami Gazdaságban. Belügyi Szemle, 1. (1963), 1. 83-89.

Kása Tibor - Fenyvesi István: Szignalizáció az állam elleni búnügyekben. Belügyi Szemle, 2. (1964), 7. 5-13.

Kiss József: Egy ellenforradalmi röpcédulaszórás nyomozásának tapasztalatai. Belügyi Szemle, 1. (1963), 8. 103-107.

Kočarov, G.: A társadalom bevonása a különösen veszélyes bủncselekmények felderítésébe. Rendőrségi Szemle, 10. (1962), 9. 821-826.

Köteles István: Az állambiztonsági munka alapja a szocialista törvényesség. Belügyi Szemle, 1. (1963), 6. 5-12.

A Magyar Népköztársaság Belügyminiszterének 0024. számú parancsa - A Belügyminisztérium szerveinek az imperialisták fellazító politikája elleni harcáról és a további feladatairól. (Belügyminisztérium, 1966. június 3.). Online: https://abparancsok.hu/sites/default/files/parancsok/10_21_24_1966.pdf

Maron, Karl: Magas képzettség - feladataink teljesítésének előfeltétele. Rendörségi Szemle, 10. (1962), 4. 376-381.

Pap János: A „Belügyi Szemle” elé.... Belügyi Szemle, 1. (1963), 1. 5-12.

A Rendőrségi Szemle búcsúja. Rendôrségi Szemle, 10. (1962), 12. 1184.

Szabó László: A rendőrség és a sajtó. Belügyi Szemle, 1. (1963), 9. 16-25.

Szerkesztőség: Előszó. Rendőrségi Szemle, 1. (1953), 1. 3-5.

Timár István: A Magyar Népköztársaság Büntető Törvénykönyvéről. Rendôrségi Szemle, 10. (1962), 1. 13-21.

Vágó Tibor: Az államrend elleni izgatás differenciálása és annak egyes kérdései a cselekmények felderítése és értékelése során. Belügyi Szemle, 1. (1963), 1. 21-28.

Vincze Béla: A parancsnokok közéleti tevékenységéről. Belügyi Szemle, 1. (1963), 1. 13-20.

\section{Jogi forrás}

1961. évi V. törvény a Büntető Törvénykönyvről 


\section{ABSTRACT}

An Overview Analysis of the Articles on the Field of State Security Published in the
(Police) Home Affairs Review after the $22^{\text {nd }}$ Congress of the Soviet Communist Party József MEZEI

From 1953, a significant part of the Hungarian state security organisations performed their duties under the Ministry of the Interior. In January of the same year, the Ministry of the Interior launched the Police Review, in particular with the aim of providing a space for sharing scientific experience in the framework of this scientific journal to guide police officers, who will be able to apply the theory more effectively in practice. Since 1963, the journal, published as the Home Affairs Review, has had several columns in which a segment of state security has been examined and presented, but from the very first year it has also had a section specifically entitled "The History of Secret Wars", which dealt entirely with it. Due to the close relationship between the party and the state security organisations, it is worth noting that the $22^{\text {nd }}$ Congress of the Soviet Communist Party took place in October 1961, while the $8^{\text {th }}$ Congress of the Hungarian Socialist Workers' Party was held in November 1962. The aim of the present study is to examine the relationship between the results of the congress and the content of the publications published in the Police (Home Affairs) Review in the field of state security after the congresses.

Keywords: state security, Home Affairs Review, response, secret war, party 